\title{
Factors that Influence the Application of Web 2.0 Based Techniques for Instructional Purposes - A Case Study
}

\author{
http://dx.doi.org/10.3991/ijet.v10i4.4529 \\ M. Batsila ${ }^{1}$, Ch. Tsihouridis ${ }^{2}$, D. Vavougios ${ }^{2}$ and G.S. Ioannidis ${ }^{3}$ \\ 1 Open University of U.K, Great Britain \\ ${ }^{2}$ Department of Special Education, University of Thessaly, Volos, Greece \\ ${ }^{3}$ The Science Laboratory, University of Patras, Patras, Greece
}

\begin{abstract}
This paper aims at investigating the factors which influence instructors of primary and secondary education into using Web 2.0 based teaching techniques in their teaching now and in the future. Two hundred and fifty three teachers participated in a survey conducted with a quantitative research method followed by short interviews for clarification purposes in the research area. The results showed that both gender and teaching experience are factors that influence this attitude, whereas the type of school seems to have no influence on educators' decision to employ such tools in their teaching practices.
\end{abstract}

Index Terms-Web 2.0, K-12, Communication Technologies, factors

\section{INTRODUCTION}

Today we are living in a world which is characterized by information explosion and where new communication systems allow us to utilize the data with relative easiness. It is called the information age as new technologies have penetrated into all areas of science and any other productive activity contributing, indirectly and directly, to their rapid evolution. To this end, today's citizens, need to be accustomed and trained in many different ways which comprise the use of ICT meant to improve all areas of our everyday lives [1]. ICT have played a very important role in education and are becoming all the more necessary for quality education and a prerequisite for personal, social, academic and professional development [2],[3],[4]. New Technologies have already come a long way offering students the unique opportunity to reach out and find information in a variety of combinations and possibilities. Additionally, they have enhanced a variety of educational courses in countries all over the world introducing attractive and innovative ways of teaching, collaborative techniques and methods and active and meaningful learning.

The magnificent rapid growth of ICT demands schools and teachers in general to be aware of their vast resources. They need to support what they have to offer and provide learners with all the necessary basic knowledge and skills needed to familiarize themselves with the new digital era of our society. As the aim of education is the creation of modern, well equipped and attractive schools for students, educators need to contribute to this quality improvement and process of effective learning by first getting accustomed with the latest technologies [5] and second introducing the use of ICT as a means to assist learners with the discovery of knowledge and exchange of ideas and opinions. Learners need to acquire the ability to explore, to seek, to discover, to collect and produce information. They must be able to manage information, to critically select what they need, to cooperate for the best solution, to learn how to learn and adapt to the demanding society of lifelong training and education.

With the introduction of new technologies, the role of the teacher is now radically changing. Just before a few years ago, teachers and textbooks were the main source of information. Henceforth, the teacher will be the organizer, the facilitator, the assistant, the person who will explain obscure points, who will direct the students and will support active and participative learning, helping them to look for the knowledge on their own. Over the last decade new tools have emerged which enhance creativity, collaboration and social interaction: the so-called Web 2.0 tools [6], [7], [8]. These refer to a term which is used to describe the fact that people socialize or interact in the Web, it is the development of Web 1.0 and displays a number of different uses. Thus, while Web 1.0 was meant for reading, websites, teaching and structure for instance and a "lonely route" to information, Web 2.0 is meant for production of written speech, discussions, brainstorming, opinions, communication and a "social journey" to knowledge. This new environment has a strong appeal to learners who use technology to introduce themselves, analyze the information and produce their work, and therefore have become the digital generation of today [9].

\section{Past Research On The SubJect}

During the previous years, Web 2.0 tools were the focus of interest for many educators, practitioners, or researchers. Theoretically, it is considered that Web 2.0 enhances on-line collaboration, cooperation, and communication between people in all aspects of personal, social, and professional life. It is seen to assist teaching and learning procedures with the use of numerous applications. However, what is the attitude teachers have towards these tools? There was in the past some considerable research interest regarding actual use of Web 2.0 tools on teaching and on teachers' attitudes towards their use. When teachers' and students' attitudes towards the Web 2.0 tools was investigated [10], it was seen that neither group used these tools either for personal or for educational purposes. Other researchers investigated the relationship between in-service teachers' self-efficacy and the integration of Web 2.0 tools in K-12 public schools in the U.S [11]. They found that (irrespective of their opinion 
about such tools) teachers were not so effective in the usage of these tools, nor did they use them frequently enough in their classes. It would seem that teachers' perceptions on the use of Web 2.0 tools in education was indeed positive in the USA, with networking sites, social video tools and podcasts being among teachers' favourite choices [12]. On the contrary, a survey conducted in India using University professors found that their interest for the application of Web 2.0 tools was very low as, according to the author, there were many obstacles to overcome for a successful implementation of these tools [13]. It is therefore seen that opinions can differ according to the country in which the investigation is made. Science teachers' usage of Web 2.0 tools was also investigated further and was correlated in relation to their gender, computer experience, or internet experience, but no differences were found regarding their actual everyday use of Web 2.0 tools. Nevertheless, when University teachers' perspectives on the use of Web 2.0 tools were explored, it was found that teachers had very positive feelings towards them [14]. Finally, though EFL teachers had a positive attitude towards Web 2.0 tools, they had to encounter various challenges such as lack of technological devices [15]. We can therefore conclude that, the attitude towards the possibility of such tools been used in schools differed radically, from country to country.

\section{Rationale For The PRESENT StUdy}

In the rapidly changing world of today, ICT have become a fundamental tool in all aspects of everyday life, including education. The global citizens of today are expected to be trained to use ICT to enhance their personal and professional skills as well as contribute to the development of their communities. ICT have come a long way and some applications emerged, are the Web 2.0 tools. Web 2.0 applications act as a tremendous source of for ICT implementation in class, allowing teachers to enhance their teaching and learners to advance their learning. They provide a vast number of resources and succeed in motivating learners, by increasing student interaction and helping them develop their critical thinking and processing skills.

Today's vast sources of available data in conjunction with the emergence of new tools to assist learning have given Primary and Secondary education teachers the ability to improve their teaching practices and differentiate their teaching approaches based on their students' needs. New ICT tools are available for introduction in classes to make learning more efficient. In fact, there are many new innovative applications, the latest developments of which are continuously introduced to interested users, while more of them are upcoming. There is, therefore a need to continuously monitor the use of such tools in everyday school practice, and this should be done in various countries around the world, because they may differ significantly. Driven by this need, the researchers decided to investigate the extent to which primary school teachers and secondary school teachers of all subjects have used or intend to use Web 2.0 tools in their classes. In Greece, teachers' formal state-sponsored training on Web 2.0 tools, concerns tools such as blogs, wikis, podcasts, rss feeds, social networks, 3D Virtual Environments, eportfolios as well as social networks, Learning Management systems and various software. Teachers' training aims to prepare them to use these tools for designing in- structive scenarios for the subject they teach. Furthermore, the researchers were also interested in finding to what extent teachers' gender, years of teaching experience and type of school they teach at (primary or secondary) affects their attitude towards the use of Web 2.0 tools.

Surprisingly however, all too often, though the existence and usefulness of Web 2.0 tools in particular is well known to a great number of young people, this does not seem to be the case with teachers, who are not aware either of their potential use or of their capabilities. Driven by this situation, the authors of this paper decided to measure the extent to which teachers are familiar with Web 2.0 tools. Specifically, the aim was to investigate whether teachers have been trained on their use, as well as the extent to which they have used them or intend to use them in their classes in the future. Most importantly however, the main aim was to find whether factors such as gender, type of school they teach (i.e. Primary vs Secondary education), or teaching experience affect their decision in using these tools.

\section{THE RESEARCH}

\section{A. Research questions}

Our main research question is what is teachers' opinion on the use of Web 2.0 tools for teaching purposes and how this is differentiated by factors such as type of school, gender and teaching experience. Conducting our research with both a quantitative and qualitative method, the research questions are as follows: (1) To what extent are teachers using Web 2.0 tools in their present teaching? (2) To what extent do teachers intend to use Web 2.0 tools in their future teaching? (3) How is this decision differentiated in relation to the type of school they teach, their gender, and their teaching experience?

\section{B. The Sample}

A sizable number of Primary and Secondary Education schoolteachers participated in the research, namely 253 teachers (139 women and 114 men), all working at different schools in Thessaly, Greece. This sample came from a great number of schools from within the county (roughly half of them), and these were randomly selected so as to be representative. As a first step, all schools were informed about the purpose of the visit and the principals' consent was asked and given. Next, the teachers, who were available at the time of the researchers' visit to the school, and volunteered to participate in the research, were asked to answer an anonymous questionnaire. Care was taken for these visits to be realised during teachers' free hours between their classes so as not to impede their teaching process. Before answering the questionnaire, all teachers were explained the purpose of the research and were informed of the questionnaire duration.

\section{Research tools}

As mentioned above, teachers' views were recorded on a questionnaire with closed type questions, mainly for practical reasons, as well as because of the effectiveness of processing codified answers in such types of questions [16]. A Non-comparative Continuous Balanced Rating scale was selected for the grading of the answers, as being the most appropriate to measure participants' attitudes and views, ranging from one (not at all) to ten (greatly) [17]. Upon completion of the questionnaires, short follow-up 
interviews, analysed with the help of content analysis method, were conducted with the teachers in order to shed more light into their answers. Finally, the research data taken from the questionnaires were digitised and were analysed using the SPSS statistical package.

\section{Short description of the questionnaire}

The purpose of the questionnaire was to collect data about Primary and Secondary school teachers' attitudes towards the use of Web 2.0 tools and how these are differentiated in relation to their gender, type of school and teaching experience. The questionnaire was composed of two parts: Part A: teachers' profile, Part B: teachers' attitudes towards Web 2.0 tools. Part A included three questions, which were the independent variables to be investigated, more of which explained below. Part B included the 2 questions, seeking answers on a scale from one (i.e. not at all) to ten (i.e. greatly), and constituted the dependent variables of the research. More analytically:

Questions of Part A: A1. Gender (male/female), A2. Type of School (Primary/Secondary), A3. Teaching experience: $<10 / 10-20 />20$. Questions of Part B: B1. To what extent have you been using the Web 2.0 tools? B2. To what extent do you intend to use them in your future classes?

\section{DATA ANALYSIS}

To investigate the influence of the factors gender, type of school (primary/secondary), and teaching experience in the use of Web 2.0 tools we used the statistical criterion of analysis of variance (factorial analysis of variance). This is a parametric criterion, which aims to study the effects of more than one independent variable on the dependent one, and their interaction. Specifically we will use the criterion Univariate Analysis of Variance (one - way Analysis of Variance-ANOVA) to study the effect of the independent variables on the dependent variable. Our research data include three factors (independent variables): factor A: Gender with levels - conditions 1: Male and 2: Female, factor B: Type of School with levels - conditions 1: Primary Education and 2: Secondary, factor C: Teaching experience with levels - conditions: $1:<10$ years, $2: 10-20$ years and 3: $>20$ years.

We consider as dependent variables of the research design the categories of the questionnaire given to teachers regarding (a) Present_Use (the use of the Web 2.0 tools so far) and (b) Future_Use (their intention to use Web 2.0 tools in the future). It should be noted that in all cases the statistical test of dispersions with the criterion of Levene's Test of Homogeneity of Variances gives a value of $p>$ 0.05 , which indicates that the null hypothesis Ho is not rejected. Therefore, there is no statistically significant difference in the dispersions of the samples and thus ANOVA can be applied in all cases.

\section{A. Influence of factor A: "Gender" on the dependent variable "Present Use" of Web 2.0 tools}

We consider the independent variable factor A: Gender with levels - conditions: 1-Male 2-Female and we will consider its effect on the dependent variable Present_Use. Firstly, we must formulate our hypotheses: Null hypothesis: There is no difference between the mean scores of factor A on the variable Present_Use (Ho: $\mathrm{m} 1=\mathrm{m} 2)$. Alternative hypothesis: There is a difference between the mean scores of factor A on the variable Present_Use (H1: $\mathrm{m} 1 \neq \mathrm{m} 2)$. The corresponding calculations of the univariate analysis of the independent samples variance are given below:

TABLE I.

Average (MEAN), Standard DeViation (StD. DEViation) AND NUMBER OF INDIVIDUALS (N) FOR EACH CONDITION OF THE INDEPENDENT VARIABLES

Present Use of Web 2.0 tools

\begin{tabular}{|l|c|c|c|c|}
\hline & $\mathbf{N}$ & Mean & Std. Deviation & Std. Error \\
\hline Male & 116 & 0.71 & 0.457 & 0.042 \\
Female & 137 & 0.50 & 0.502 & 0.043 \\
Total & 253 & 0.59 & 0.492 & 0.031 \\
\hline
\end{tabular}

TABLE II.

UNIVARIATE ANALYSIS OF VARIANCE OF THE DEPENDENT VARIABLE "PRESENT USE" ON WEB 2.0 TOOLS

Present Use of Web 2.0 tools

\begin{tabular}{|l|c|c|c|c|c|}
\hline & $\begin{array}{c}\text { Sum of } \\
\text { Squares }\end{array}$ & df & $\begin{array}{c}\text { Mean } \\
\text { Square }\end{array}$ & F & Sig. \\
\hline Between Groups & 2.785 & 1 & 2.785 & 11.992 & 0.001 \\
Within Groups & 58.283 & 251 & 0.232 & & \\
Total & 61.067 & 252 & & & \\
\hline
\end{tabular}

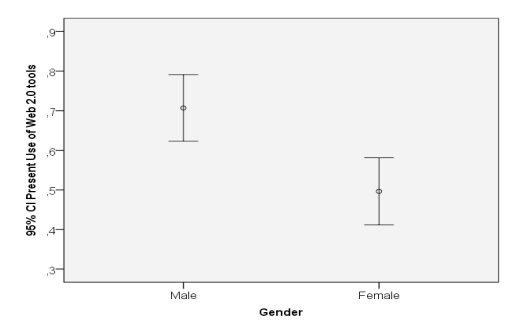

Figure 1. Error graph for the two research groups of the variable "Gender" on the variable "Present Use" on Web 2.0 tools

The statistical presentation of the above result is: $\mathrm{F}$ $(1.251)=11.992, p=0.001$. Since the calculated value of F: 11.992 is larger than the critical value 3.84 we accept the alternative hypothesis and conclude that gender affects the Present_Use of Web 2.0 tools. This is also shown on the above error graph where there is no overlap of the error bars with a statistically significant result. More specifically men teachers use Web 2.0 tools in higher proportion than women teachers in this phase.

\section{B. Influence of factor B: "Type of School" on the dependent variable "Present Use" of Web 2.0 tools}

We consider the independent variable factor B: Type of School with levels - conditions 1: Primary and 2: Secondary and we will examine its effect on the dependent variable Present_Use. Firstly, we will formulate our hypotheses: Null hypothesis: There is no difference between the mean scores of factor B on the variable Present_Use (Ho: $\mathrm{m} 1=\mathrm{m} 2)$. Alternative hypothesis: There is a difference between the mean scores of factor $\mathrm{B}$ on the variable Present_Use $(\mathrm{H} 1: \mathrm{m} 1 \neq \mathrm{m} 2)$. The corresponding calculations of univariate analysis of the independent samples variance are given below: 
TABLE III.

AVERAGE (MEAN), STANDARD DEVIATION (STD. DEVIATION) AND NUMBER OF INDIVIDUALS (N) FOR EACH CONDITION OF THE INDEPENDENT VARIABLES

Present Use of Web 2.0 tools

\begin{tabular}{|l|c|c|c|c|}
\hline & N & Mean & Std. Deviation & $\begin{array}{c}\text { Std. } \\
\text { Error }\end{array}$ \\
\hline Primary & 131 & 0.59 & 0.494 & 0.043 \\
Secondary & 122 & 0.60 & 0.492 & 0.045 \\
Total & 253 & 0.59 & 0.492 & 0.031 \\
\hline
\end{tabular}

TABLE IV.

UNIVARIATE ANALYSIS OF VARIANCE OF THE DEPENDENT VARIABLE "PRESENT USE" ON WEB 2.0 TOOLS

Present Use of Web 2.0 tools

\begin{tabular}{|l|c|c|c|c|c|}
\hline & $\begin{array}{c}\text { Sum of } \\
\text { Squares }\end{array}$ & df & $\begin{array}{c}\text { Mean } \\
\text { Square }\end{array}$ & F & Sig. \\
\hline Between Groups & 0.007 & 1 & 0.007 & 0.029 & 0.865 \\
Within Groups & 61.060 & 251 & 0.243 & & \\
Total & 61.067 & 252 & & & \\
\hline
\end{tabular}

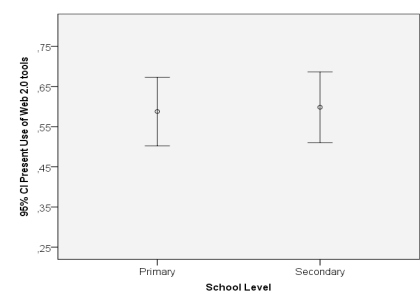

Figure 2. Error graph for the two research groups of the variable

"Type of School" on the variable "Present Use" on Web 2.0 tools

The presentation of the above result is: $\mathrm{F}(1.251)=$ $0.029, \mathrm{p}=0.865$. Since the calculated value of $F: 0.029$ is less than the critical value 3.84 we accept the null hypothesis and conclude that the Type of school does not affect the Present Use of Web 2.0 tools. This is also shown on above the error graph where there is an overlap of the error bars and a statistically not significant result.

\section{Influence of factor C: "Teaching Experience" on the} dependent variable "Present Use" of Web 2.0 tools

We consider the independent variable factor C: Teaching Experience with levels - conditions 1: $<10$ years, 2: 10-20 years and 3: $>20$ years, and we will study its effect on the dependent variable Present Use. Firstly, we need to formulate the hypotheses: Null hypothesis: There is no difference between the mean scores of factor $\mathrm{C}$ on the variable Present Use (Ho: $\mathrm{m} 1=\mathrm{m} 2=\mathrm{m} 3)$. Alternative hypothesis: There is a difference between the mean scores of factor $\mathrm{C}$ on the variable Present Use $(\mathrm{H} 1: \mathrm{m} 1 \neq \mathrm{m} 2 \neq$ $\mathrm{m} 3)$. The corresponding calculations of univariate analysis of the independent samples variance are given in Tables $\mathrm{V}$ and VI.

The presentation of the above result is: $F(2.250)=$ $31.318, \mathrm{p}=<0.001$. Since the calculated value of $\mathrm{F}$ : 31.318 is larger than the critical value 3.00 we accept the alternative hypothesis and conclude that the years of experience affect the Present Use of Web 2.0 tools. Thus, a minimum average statistically significant is different from
TABLE V.

Average (MEAN), Standard DEVIATION (STD. DEVIATION) AND NUMBER OF INDIVIDUALS (N) FOR EACH CONDITION OF THE INDEPENDENT VARIABLES

Present Use of Web 2.0 tools

\begin{tabular}{|l|c|c|c|c|}
\hline & N & Mean & Std. Deviation & Std. Error \\
\hline$<10$ years & 78 & 0.83 & 0.375 & 0.042 \\
$10-20$ years & 91 & 0.66 & 0.477 & 0.050 \\
$>$ 20 years & 84 & 0.30 & 0.460 & 0.050 \\
Total & 253 & 0.59 & 0.492 & 0.031 \\
\hline
\end{tabular}

TABLE VI.

UNIVARIATE ANALYSIS OF VARIANCE OF THE DEPENDENT VARIABLE "PRESENT USE" ON WEB 2.0 TOOLS

Present Use of Web 2.0 tools

\begin{tabular}{|l|l|l|l|l|l|}
\hline & \multicolumn{1}{|c|}{$\begin{array}{c}\text { Sum of } \\
\text { Squares }\end{array}$} & \multicolumn{1}{|c|}{ df } & $\begin{array}{c}\text { Mean } \\
\text { Square }\end{array}$ & \multicolumn{1}{|c|}{ F } & Sig. \\
\hline Between Groups & 12.235 & 2 & 6.117 & 31.318 & 0.000 \\
Within Groups & 48.832 & 250 & 0.195 & & \\
Total & 61.067 & 252 & & & \\
\hline
\end{tabular}

TABLE VII. UNIVARIATE ANALYSIS OF VARIANCE OF THE DEPENDENT VARIABLE “PRESENT USE” ON WEB 2.0 TOOLS

Present Use of Web 2.0 tools Tukey HSD

\begin{tabular}{|l|l|c|c|c|}
\hline $\begin{array}{c}\text { (I) Teaching } \\
\text { experience }\end{array}$ & $\begin{array}{c}\text { (J) Teaching } \\
\text { experience }\end{array}$ & $\begin{array}{c}\text { Mean Difference } \\
\text { (I-J) }\end{array}$ & $\begin{array}{c}\text { Std. } \\
\text { Error }\end{array}$ & Sig. \\
\hline$<10$ years & $10-20$ years & $0.174^{*}$ & 0.068 & 0.030 \\
& $>$ 20 years & $0.536^{*}$ & 0.069 & 0.000 \\
$10-20$ years & $<10$ years & $-0.174^{*}$ & 0.068 & 0.030 \\
& $>20$ years & $0.362^{*}$ & 0.067 & 0.000 \\
$>20$ years & $<10$ years & $-0.536^{*}$ & 0.069 & 0.000 \\
& $10-20$ years & $-0.362^{*}$ & 0.067 &, 0.000 \\
\hline
\end{tabular}

*. The mean difference is significant at the 0.05 level.

at least another average. For this reason, we use the statistical criteria of multiple comparisons (multiple comparisons tests) that allow us to make various comparisons between the means of the research conditions. Therefore, we use the criterion Tukey HSD (Honestly Significant Difference) which is considered the safest criterion of a researcher who wants to make all possible comparisons between the two averages.

From the results of Table VII it is evident that all possible differences of averages are statistically significant, and specifically: (a) the difference between the mean scores of the research condition Teaching Experience $<10$ years and the research condition Teaching Experience $10-20$ years is $17.4 \%$ (Mean Difference $=0.174, p=0.03$ ). Also, (b) the difference between the averages of research condition Teaching Experience $<10$ years and the research condition Teaching Experience $>20$ years is $+53.6 \%$ (Mean Difference $=0.536, p<0,001)$ and (c) the difference between the averages of the research condition Teaching Experience $10-20$ years and the research condition Teaching Experience $>20$ years is $+36.2 \%$ (Mean Difference $=0.362, \mathrm{p}$ $<0.001)$. This means that younger teachers in service make use of the web 2.0 tools in their present teaching although all groups regardless of their years of service have been trained on the use of Web 2.0 tools equally. The 
result is also shown on the following error graph where there is no overlap of the error rods showing a statistically significant result.

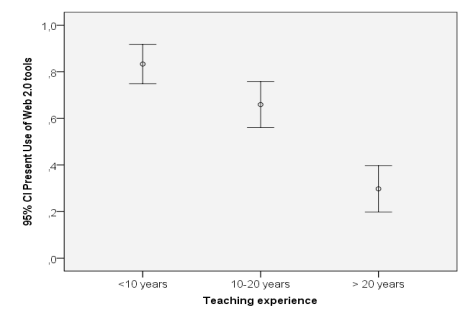

Figure 3. Error graph for the two research groups of the variable "Teaching Experience" on the variable "Present Use" on Web 2.0 tools

\section{Influence of factor A: "Gender" on the dependent variable "Future Use" of Web 2.0 tools}

We consider the independent variable factor A: Gender with levels - conditions: 1-Male, 2-Female and we will examine its effect on the dependent variable Future Use. Firstly, we will formulate the hypotheses: Null hypothesis: There is no difference between the average levels of factor A on the dependent variable Future_Use (Ho: $\mathrm{m} 1=\mathrm{m} 2)$. Alternative hypothesis: There is a difference between the average levels of factor A on the variable Future_Use (H1: $\mathrm{m} 1 \neq \mathrm{m} 2)$. The corresponding calculations of univariate analysis of variance independent samples are given below:

TABLE VIII

Average (Mean), Standard DeViation (STD. Deviation) AND NUMBER OF INDIVIDUALS (N) FOR EACH CONDITION OF THE INDEPENDENT VARIABLES

Future Use of Web 2.0 tools

\begin{tabular}{|l|c|c|c|c|}
\hline & N & Mean & $\begin{array}{c}\text { Std. Devia- } \\
\text { tion }\end{array}$ & Std. Error \\
\hline Male & 116 & 7.54 & 2.426 & 0.225 \\
Female & 137 & 4.68 & 2.698 & 0.230 \\
Total & 253 & 5.99 & 2.943 & 0.185 \\
\hline
\end{tabular}

TABLE IX.

UNIVARIATE ANALYSIS OF VARIANCE OF THE DEPENDENT VARIABLE "FUTURE USE" ON WEB 2.0 TOOLS

Future Use of Web 2.0 tools

\begin{tabular}{|l|c|c|c|c|c|}
\hline & $\begin{array}{c}\text { Sum of } \\
\text { Squares }\end{array}$ & df & $\begin{array}{c}\text { Mean } \\
\text { Square }\end{array}$ & F & Sig. \\
\hline Between Groups & 515.331 & 1 & 515.331 & 77.609 & 0.000 \\
Within Groups & 1666.653 & 251 & 6.640 & & \\
Total & 2181.984 & 252 & & & \\
\hline
\end{tabular}

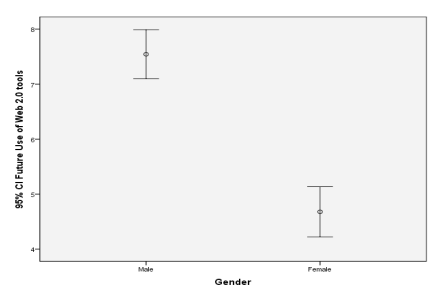

Figure 4. Error graph for the two research groups of the variable "Gender" on the variable "Future Use" on Web 2.0 tools

The statistical presentation of the above result is: $\mathrm{F}$ $(1.251)=77.609, p<0.001$. Since the calculated value of
F:77.609 is larger than the critical value 3.84 we accept the alternative hypothesis and conclude that gender affects the Future_Use of Web 2.0 tools. This is shown on the error graph where there is no overlap of error bars. More specifically men teachers intend to use Web 2.0 tools in higher proportion than women teachers in the near future.

\section{E. Influence of factor B: "Type of School" on the dependent variable "Future Use" of Web 2.0 tools}

We consider the independent variable factor B: Type of School with levels - conditions 1: Primary and 2: Secondary and we will look into its effect on the dependent variable Future Use. Firstly, we formulate our hypotheses: Null hypothesis: There is no difference between the mean score of factor B on the variable Future Use (Ho: $\mathrm{ml}=$ $\mathrm{m} 2$ ). Alternative hypothesis: There is a difference between the mean scores of factor B on the variable Future Use $(\mathrm{H} 1: \mathrm{m} 1 \neq \mathrm{m} 2)$. The corresponding calculations of univariate analysis of the independent samples variance are given below:

TABLE X.

AVERAGE (MEAN), Standard DeViation (StD DeViation) AND NUMBER OF INDIVIDUALS (N) FOR EACH CONDITION OF THE INDEPENDENT VARIABLES

Future Use of Web 2.0 tools

\begin{tabular}{|l|c|c|c|c|}
\hline & N & Mean & Std. Deviation & Std. Error \\
\hline Primary & 131 & 6.01 & 3.080 & 0.269 \\
Secondary & 122 & 5.98 & 2.800 & 0.254 \\
Total & 253 & 5.99 & 2.943 & 0.185 \\
\hline
\end{tabular}

TABLE XI.

UNIVARIATE ANALYSIS OF VARIANCE OF THE DEPENDENT VARIABLE "FuTURE USE" ON WEB 2.0 TOOLS

Future Use of Web 2.0 tools

\begin{tabular}{|l|c|c|c|c|c|}
\hline & $\begin{array}{c}\text { Sum of } \\
\text { Squares }\end{array}$ & Df & $\begin{array}{c}\text { Mean } \\
\text { Square }\end{array}$ & F & Sig. \\
\hline Between Groups & 0.066 & 1 & 0.066 & 0.008 & 0.931 \\
Within Groups & 2181.919 & 251 & 8.693 & & \\
Total & 2181.984 & 252 & & & \\
\hline
\end{tabular}

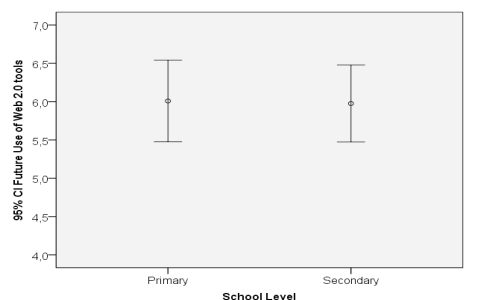

Figure 5. Error graph for the two research groups of the variable "Type of School" on the variable "Future Use" on Web 2.0 tools

The presentation of the above result is: $\mathrm{F}(1.251)=$ $0.008, p=0.931$. Since the calculated value of $F: 0.008$ is less than the critical value 3.84 we accept the null hypothesis and conclude that the type of school does not affect the Future Use of Web 2.0 tools. This is shown on the error graph where there is an overlap of the error bars showing a statistically not significant result. 


\section{F. Influence of factor C: "Teaching Experience" on the} dependent variable "Future Use" of Web 2.0 tools

We consider the independent variable factor C: Teaching Experience with levels - conditions 1: $<10$ years, 2: 10-20 years and 3: $>20$ years, and we will examine its effect on the dependent variable Future Use. Firstly, we formulate our hypotheses: Null hypothesis: There is no difference between the mean scores of factor $\mathrm{C}$ on the variable Future Use (Ho: $\mathrm{m} 1=\mathrm{m} 2=\mathrm{m} 3$ ). Alternative hypothesis: There is a difference between the mean score of factor $\mathrm{C}$ on the variable Future Use $(\mathrm{H} 1: \mathrm{m} 1 \neq \mathrm{m} 2 \neq$ $\mathrm{m} 3)$. The corresponding calculations of univariate analysis of the independent samples variance are given below:

TABLE XII

AVerage (Mean), Standard DeViation (STD. Deviation) And NUMBER OF INDIVIDUALS (N) FOR EACH CONDITION OF THE INDEPENDENT VARIABLES

Future Use of Web 2.0 tools

\begin{tabular}{|l|c|c|c|c|}
\hline & N & Mean & $\begin{array}{c}\text { Std. Devia- } \\
\text { tion }\end{array}$ & Std. Error \\
\hline$<10$ years & 78 & 6.87 & 2.499 &, 283 \\
10-20 years & 91 & 6.23 & 2.956 &, 310 \\
$>$ 20 years & 84 & 4.92 & 3.011 &, 329 \\
Total & 253 & 5.99 & 2.943 &, 185 \\
\hline
\end{tabular}

TABLE XIII.

UNIVARIATE ANALYSIS OF VARIANCE OF THE DEPENDENT VARIABLE "FUTURE USE" ON WEB 2.0 TOOLS

Future Use of Web 2.0 tools

\begin{tabular}{|l|c|c|c|c|c|}
\hline & $\begin{array}{c}\text { Sum of } \\
\text { Squares }\end{array}$ & df & $\begin{array}{c}\text { Mean } \\
\text { Square }\end{array}$ & F & Sig. \\
\hline Between Groups & 162.696 & 2 & 81.348 & 10.071 & 0.000 \\
Within Groups & 2019.288 & 250 & 8.077 & & \\
Total & 2181.984 & 252 & & & \\
\hline
\end{tabular}

The presentation of the above result is: $F(2,250)=$ $10,071, p<0,001$. Since the calculated value of F: 10.071 is larger than the critical value 3.00 we accept the alternative hypothesis and conclude that the type of school affects the Future Use of Web 2.0 tools. Thus, a minimum average statistically significant is different from at least another average. For this reason, we use the statistical criteria of multiple comparisons (multiple comparisons tests) that allow us to make various comparisons between the means of the research conditions. For this reason, we use the criterion Tukey HSD (Honestly Significant Difference - honest significant difference).

From the results of table 20 it is obvious that the only differences in averages which are statistically significant are: (a) the difference between the averages of the research condition Teaching Experience $<10$ years and the research condition Teaching Experience $>20$ years is $19.55 \%$ ( Mean Difference $=1.955, \mathrm{p}<0,001)$. Also, (b) the difference between the averages of the research condition Teaching Experience 10 -20 years and the research condition Teaching Experience $>20$ years is $+13.14 \%$ (Mean Difference $=1.314, p=0.007)$. This means that the teachers with less years of teaching service intend to use web 2.0 tools in their future teaching although all
TABLE XIV.

UNIVARIATE ANALYSIS OF VARIANCE OF THE DEPENDENT VARIABLE "FUTURE USE" ON WEB 2.0 TOOLS

Future Use of Web 2.0 tools Tukey HSD

\begin{tabular}{|l|l|c|c|c|}
\hline $\begin{array}{c}\text { (I) Teaching } \\
\text { experience }\end{array}$ & $\begin{array}{c}\text { (J) Teaching } \\
\text { experience }\end{array}$ & $\begin{array}{c}\text { Mean Difference } \\
\text { (I-J) }\end{array}$ & $\begin{array}{c}\text { Std. } \\
\text { Error }\end{array}$ & Sig. \\
\hline$<10$ years & $10-20$ years & 0.641 & 0.439 & 0.311 \\
& $>20$ years & $1.955^{*}$ & 0.447 & 0.000 \\
$10-20$ years & $<10$ years & -0.641 & 0.439 & 0.311 \\
& $>20$ years & $1.314^{*}$ & 0.430 & 0.007 \\
$>20$ years & $<10$ years & $-1.955^{*}$ & 0.447 & 0.000 \\
& $10-20$ years & $-1.314^{*}$ & 0.430 & 0.007 \\
\hline
\end{tabular}

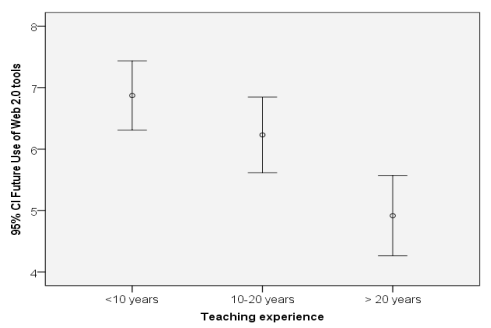

Figure 6. Error graph for the two research groups of the variable "Teaching Experience" on the variable "Future Use" on Web 2.0 tools

groups with respect to years of service have been trained on the use of Web 2.0 tools equally. The result is shown in Figure 6 , where the error graph, by comparing the first with the third point, and also the second with the third, supports the aforementioned findings.

\section{DISCUSSION AND CONCLUSIONS}

The results of this research revealed that several factors affect the teaching community' decision to apply Web 2.0 based techniques in their teaching. More specifically, it was found that teachers' decision to use Web 2.0 tools in their present practices is indeed affected by gender. It is worth noticing that male teachers tend to use them to a greater extent than their female colleagues. Additionally, the factor "working experience" also influences the present use of the new tools whereas most surprisingly, it is the teachers with less experience that are most likely the ones to use them despite the fact that they all had the same training regardless of years of service. Our short interviews with the teachers gave us a clearer idea towards the issue revealing that despite the fact that teachers with more years of service find Web 2.0 tools fascinating, they are not so willing to use them as they feel inadequate and fear this might cause their being ridiculed by their learners and colleagues. They also feel that the specific tools are rather time consuming but added however that even if they wished to employ them in their teaching it would not be possible as the only lab in their school rendered the task really unfeasible.

Similarly, the factor "gender" influences teachers' intention to use Web 2.0 tools in the future with male ones planning to do it in higher proportion than female teachers do. Moreover, though the type of school they work does not affect their intention to use Web 2.0 tools in their future practice, their teaching experience does seem to have an influence on their decision to use these tools in the future. The short interviews revealed that low self- 
esteem is probably what impedes them from using them as once more teachers with more years of service believe they cannot make a difference now, as they feel they need a lot of work to get accustomed to their usage. A similar attitude was detected for women who complained that family obligations and lack of free time are the basic reasons for being more sceptical to use Web 2.0 tools.

We would like to point out here that this was a first attempt to detect which factors influence teachers' decision to Web 2.0 tools. As effective teaching involves new methods and tools, it is crucial to have our teachers well prepared in order to meet the new challenges. ICT are evolving continuously and in sometimes unexpected ways. As young learners are consistently a step ahead than the rest, there is an urgent need to discover the right way to enhance the pace of Web 2.0 tool adoption in class. Specialist educational tools as well as help to the teachers may be essential, so as to keep abreast with the constantly expanding instructive needs. Thus, a second part of this study will follow, combining both a larger sample, with a more targeted qualitative study, to reveal possible ways to achieve this goal.

New technologies and particularly Web 2.0 tools offer a vast source of modern applications for the benefit of improving our daily routines, amongst which education being one of the most important beneficiaries. Whilst each country aspires to development (economic, technological, scientific etc.) it is literally depended on new technologies and their constantly updated applications. Education has a lot to benefit from their use and exploitation as they strengthen the teaching and learning process, promote cognitive awareness, offer quality support and augment the prerequisites for growth and improvement. In this challenging pathway teachers need to abide with the new approach and its demands and prepare themselves for effective teaching and innovative techniques. Web 2.0 tools have many benefits to offer with student socialization, collaboration and exchange of views being very significant. Web 2.0 tools create a positive attitude towards social behavior; they support the development of learning communities, offer a positive incentive for active class participation, enhance communication and interactivity in school life and are easy to use. Teachers need to overcome their fear and allow themselves to get accustomed to new ideas and methods. Governments need to be aware of this and implement such training programs which will eliminate fear and stress on behalf of the teachers and support them in their effort to get prepared for the new digital educational era of today, allowing them to succeed in their difficult but crucial new role. This is no other but the supportive role of a mentor in the difficult, yet, such an enchanting process of the teaching and learning magnificent world of education.

\section{REFERENCES}

[1] S. R. Zahedi and S. M. Zahedi, Role of Information and Communication Techonlogies in Modern Agriculture, International Journal of Agriculture and Crop Sciences (IJACS), vol. 4 (23), pp. $1725-1728,2012$

[2] F. Mikre, The Roles of Information Communication Technologies in Education, Review Article with Emphasis to the Computer and Internet, Ethiopian Journal of Education \& Sciences, vol. 6 (2), retrieved November 10, 2013 from:

http://www.ajol.info/index.php/ejesc/article/viewFile/73521/62437
[3] R. Andrews, "Where next in research on ICT and literacies?" English in Education, vol. 37 (3), pp. 28-41, 2003 http://dx.doi.org/10.1111/j.1754-8845.2003.tb00603.x

[4] G. Kress, Literacy in the New Media Age, London: Routledge, 2003 http://dx.doi.org/10.4324/9780203164754

[5] S. Schuck, P. Aubuson and Kearney, Web 2.0 in the Classroom? Dilemmas and Opportunities Inherent in Adolescent Web 2.0 Engagement, Contemporary Issues in Technology and Teacher Education, vol. 10 (2), pp. 234-246, 2010

[6] P. Anderson, What is Web 2.0? "Ideas, technologies and implications for education", JISC, Technology \& Standards Watch, February 2007

[7] A. Ebersbach, M. Glasser and R. Heigl, Wiki: Web Collaboration. Germany: Springer-Verlag, 2006

[8] T. Franklin and M. Van Harmelen, Web 2.0 for Content for Learning and Teaching in Higher Education, 28 May 2007

[9] A. C. M. O. Robles, "The Use of Educational Web Tools: An Innovative Technique in Teacher Education Courses", I.J. Modern Education and Computer Science, vol. 3, pp. 34-40, 2013 http://dx.doi.org/10.5815/ijmecs.2013.02.05

[10] A. A. Sebah, Understanding teachers' and students' use and attitudes of Web 2.0 in ESL classrooms at the American University of Sharjah, A thesis in teaching English to speakers of other languages, Master of Arts, Sharijah, UAE, May 2010

[11] S. C. Pan and T. Franklin, "In-Service Teachers' Self-Efficacy, Professional Development and Web 2.0 Tools for Integration", New Horizons in Education, Vol. 59 (3), pp. 28-40, December 2011

[12] R. Khany and M. Boghayeri, "The use of Web 2.0 tools in language pedagogy: an Iranian EFL teachers' attitude", Proceedings of the Global Summit on Education (GSE2013), Kuala Lumpur, pp. 151-159, 11-12 March 2013

[13] S. Tyagi, "Adoption of Web 2.0 technology in higher education: A case study of universities in National Capital Region, India", International Journal of Education and Development using information and Communication Technology (IJEDICT), vol.8 (2), pp. $28-43,2012$

[14] S. Kumar and K. Vigil, "Pre-service Teachers' Perspectives on Web 2.0 Integration in Teacher Education Courses", available at: http://www.academia.edu/772289/Pre-serviceTeachers Perspectives on Web 2.0 Integration in Teacher Education Courses, Retrieved October 9, 2014

[15] P.T. Cephe and C.B. Balcinanli, "Web 2.0 tools in language teaching: what do student teachers think?", International Journal on New Trends in Education and Their Implications, ijonte, January, February, March 2012, Vol. 3 (1), 2012

[16] J. P. Dillard, Building Capacity in Evaluating Outcomes, Adapted from UFIFAS, Washington County Extension, University of Wisconsin (2008), Washington Country Extension: UF IFAS

[17] W. P. Vogt, Dictionary of statistics and methodology, $4^{\text {th }}$ edition, Thousand Oaks, California: Sage Publications, ISBN 978-1-41297109-6 (pbk.)

\section{AUTHORS}

M. Batsila is with the Directorate of Secondary Education, Greece (e-mail: marbatsila@gmail.com).

Ch. Tsihouridis is with the Department of Special Education, University of Thessaly, Greece (e-mail: hatsihour@uth.gr).

G.S. Ioannidis is with The Science Laboratory, Universiy of Patras, Greece (e-mail: gsioanni@upatras.gr).

D. Vavougios is with the Department of Special Education, University of Thessaly, Greece (e-mail: dvavou@uth.gr).

Submitted 15 March 2015. Published as resubmitted by the authors 20 August 2015. 